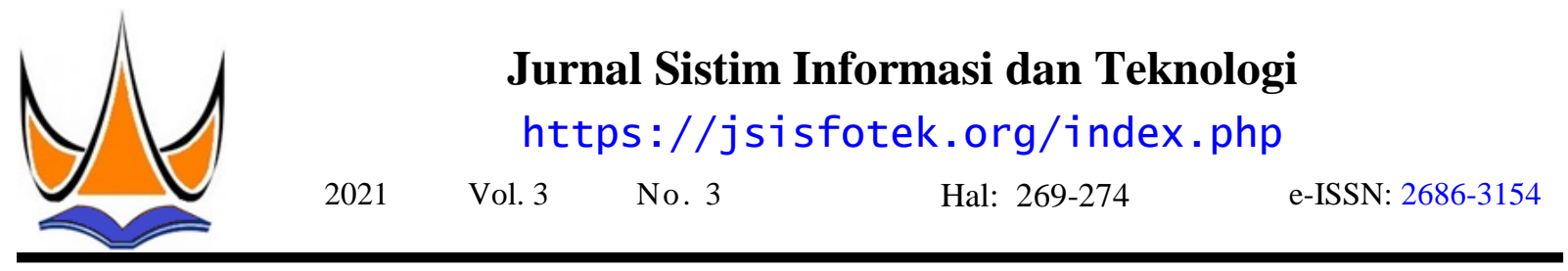

\title{
Sistem Pakar dalam Menganalisis Penyakit Kelenjar Getah Bening Menggunakan Metode Certainty Factor
}

\author{
Sri Layli Fajri ${ }^{1 凶}$, Gunadi Widi Nurcahyo ${ }^{2}$ \\ ${ }^{1}$ Independent Researcher \\ ${ }^{2}$ Universitas Putra Indonesia YPTK Padang \\ sri1ay1i26@gmai1.com
}

\begin{abstract}
In general, a person is difficult do dermine whether a lump or swelling of the lymph nodes in the body, is just a normal lump or whether it has become cancer. If the lumph does not go away whitin a few days, the patient is required to immediately consult a doctor to get detailed information about the disease and how to treat it. Lymph nodes scattered in the human body are round and are part of the lymphatic system that plays a role in fighting viruses that enter the body. The cause of these enlarged lymph nodes can be due to the type of food consumed, congenital disease in the patient's body (comorbid), infection to lymph node cancer (lymphoma). For this reason, an Expert System is needed by applying the Certainty Factor method in order to assist the public in analyzing lymph node disease by answering several questions regarding the symptoms experienced. This system is implementad using the PHP programming language and MySQL database. The result of this study show that the Certainty Factor method can work well in the Expert System analysis process. From the result of system trials with several patient data, the disease accuracy rate in the patient named $\mathrm{S}$ is $63 \%$ and the disease accuracy rate in the patient named MR is $68 \%$. Besides being useful for an expert, this Expert System can help patients to find out the type of disease they are suffering from, the accuracy of disease, the method of treatment and a guide for making decisions.
\end{abstract}

Keywords: Lymph node, Certainty Factor, Expert System, PHP, MySQL.

\begin{abstract}
Abstrak
Pada umumnya, seseorang sulit menentukan apakah benjolan atau pembengkakan kelenjar getah bening di tubuh, hanya benjolan biasa ataukah itu sudah menjadi kanker. Apabila benjolan tidak hilang dalam beberapa hari, pasien diharuskan untuk berkonsultasi ke dokter agar dapat informasi detail mengenai penyakit dan bagaimana cara penanganan medisnya. Kelenjar getah bening tersebar dalam tubuh manusia yang berbentuk bulat dan merupakan bagian dari sistem limfatik yang berperan dalam melawan virus yang masuk ke dalam tubuh. Penyebab kelenjar getah bening ini mengalami pembesaran bisa karena jenis makanan yang dikonsumsi, penyakit bawaan pada tubuh pasien (comorbid), infeksi sampai kanker kelenjar getah bening (limfoma). Untuk itu, dibutuhkan Sistem Pakar dengan menerapkan metode Certainty Factor agar dapat membantu masyarakat dalam menganalisis penyakit kelenjar getah bening dengan menjawab beberapa pertanyaan mengenai gejalagejala yang dialami. Sistem ini diimpletasikan menggunakan bahasa pemrogramn PHP dan database MySQL. Hasil penelitian ini menunjukkan bahwa metode Cetainty Factor dapat bekerja dengan baik dalam proses analisis Sistem Pakar. Dari hasil ujicoba sistem dengan beberapa data pasien, tingkat akurasi penyakit pada pasien bernama S sebesar 63\% dan tingkat akurasi penyakit pada pasien bernama MR sebesar 68\%. Selain bermanfaat bagi pakar, Sistem Pakar ini dapat membantu pasien untuk mengetahui jenis penyakit yang diderita, tingkat akurasi penyakit, cara penggobatan dan sebagai pedoman untuk mengambil keputusan
\end{abstract}

Kata kunci: Kelenjar getah bening, Certainty Factor, Sistem Pakar, PHP, MySQL.

(C) 2021 JSisfotek

\section{Pendahuluan} Kelenjar getah bening ialah struktur jaringan kecil yang kelenjar yang mengalami pembesaran dapat dilihat tersebar di seluruh bagia tubuh, bagian ini berperan pada Gambar 1. sebagai sistem kekebalan pada tubuh manusia. Sistem kekebalan sering disebut juga sebagai sistem imun. Sistem ini memiliki jutaan sel yang berfungsi untuk menangkal radikal bebas yang dapat menyerang dan menimbulkan berbagai macam penyakit. Sedangkan kelenjar getah bening berfungsi sebagai pusat pemrosesan informasi, jaringan deteksi dan respon terdistribusi. Dan terjadinya pembengkakan kelenjar getah bening adalah kondisi di mana kelenjar getah bening mengalami pembesaran karena reaksi terhadap banyaknya sel imun yang dihasilkan oleh kelenjar getah bening untuk melawan zat yang membahayakan tubuh [1]. Perbedaan kelenjar getah bening normal dan

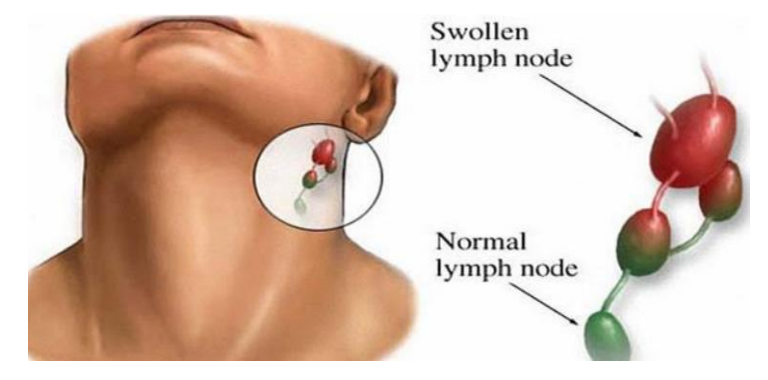


Gambar 1. Swallen Lymph Node \& Normal Lymph Node

Metode Certainty Factor (faktor kepastian) merupakan suatu metode cara penggabungan kepercayaan (belief) dan ketidakpercayaan (disbelief) yang bisa digunakan dalam mengatasi ketidakpastian pemikiran (inexact reasoning) berupa suatu informasi atau fakta dari seorang pakar. Meskipun seorang pakar ahli di bidangnya, seorang pakar juga memiliki keterbatasan stamina kerja dan daya ingat yang menurun karena faktor usia. Sehingga, seorang pakar juga bisa membuat kesalahan saat proses analis dan pengambilan keputusan. Untuk itu, seorang peneliti atau pakar berusaha mencari solusi pemecahan masalah dengan penerapan Sistem Pakar (Expert System) menggunakan berbagai macam metode [2].

Penelitian sebelumnya dengan penerapan metode Certainty Factor pada objek yang berbeda, membahas masalah yang dihadapi oleh masyarakat mengenai faktor penyebab terjadinya bencana alam banyak terjadi di dunia. Salah satu dari bencana alam yaitu tanah longsor yang terjadi di Cina. Untuk mengurangi resiko bencana, maka peneliti dari Cina melakukan penelitian penyebab kejadian tersebut dengan dilakukannya penilaian kerentanan tanah longsor menggunakan tiga metode yaitu Evidential Belief Function, Certainty Factor dan Frequency Ratio berdasarkan faktor lingkungan dengan hasil analisis yang didapatkan yaitu $0.8056,0.7922$ dan 0.7988 [3]. Dalam studi kasus yang sama, evaluasi tingkat kerentanan tanah longsor menggunakan Funtional Trees Based Ensemble Techniques memiliki tingkat prediksi tinggi dari pada metode Certainty Factor [4]. Dan penelitian kerentanan tanah longsor di kabupaten Wen menggunakan metode Certainty Factor lebih memiliki akurasi yang tinggi dibandingkan dengan metode Information Value dan Weights of Evidence [5]. Sedangkan dalam mengatasi masalah kasus penilaian potensi panas bumi yang terjadi di kabupaten Tenchong menggunakan Certainty Factor menunjukkan hasil prediksi yang lebih akurat [6].

Penelitian sebelumnya juga membahas penerapan metode Certainty Factor dalam masalah yang dihadapi oleh petani tanaman cabai. Mereka mengalami banyak kerugian seperti gagal panen yang menyebabkan kuantitas pemasokan cabai berkurang akibat penyakit dan beberapa jenis hama yang menyerang tanaman mereka. Untuk mendapatkan kepercayaan atau kepastian permasalahan tersebut, maka dibangun Sistem Pakar untuk mendeteksi penyakit tanaman cabai menggunakan metode Certainty Factor sehingga didapatkan hasil analisis $77,58 \%$ berhasil mendeteksi penyakit tanaman cabai [7]. Analisis dan pendeteksian awal sangat perlu dilakukan untuk mencegah tingkat keparahan suatu masalah. Salah satunya yaitu dalam menganalisis suatu penyakit. Pada penelitian dalam mendeteksi permanen kebutaan yang diakibatkan oleh penyakit glaukoma, penerapan Sistem Pakar membantu dalam pemeriksaan glaukoma dengan tingkat akurasi [8].

\section{Metodologi Penelitian}

Istilah metodologi berbeda dengan metode, di mana metodologi merupakan prinsip dasar penelitian, apa yang hendak dilakukan oleh peneliti dalam menjawab pertanyaan-pertanyaan penelitian. Sedangkan metode adalah teknik penerapannya dalam mencari, merumuskan, menganalisis hingga menyusun laporan berdasarkan fakta-fakta secara ilmiah untuk memperoleh pemahaman tentang sasaran yang telah ditetapkan sebelumnya. Agar penelitian lebih mudah dipahami perlu adanya kerangka kerja (frame work). Kerangka kerja penelitian yang digunakan seperti pada Gambar 2.

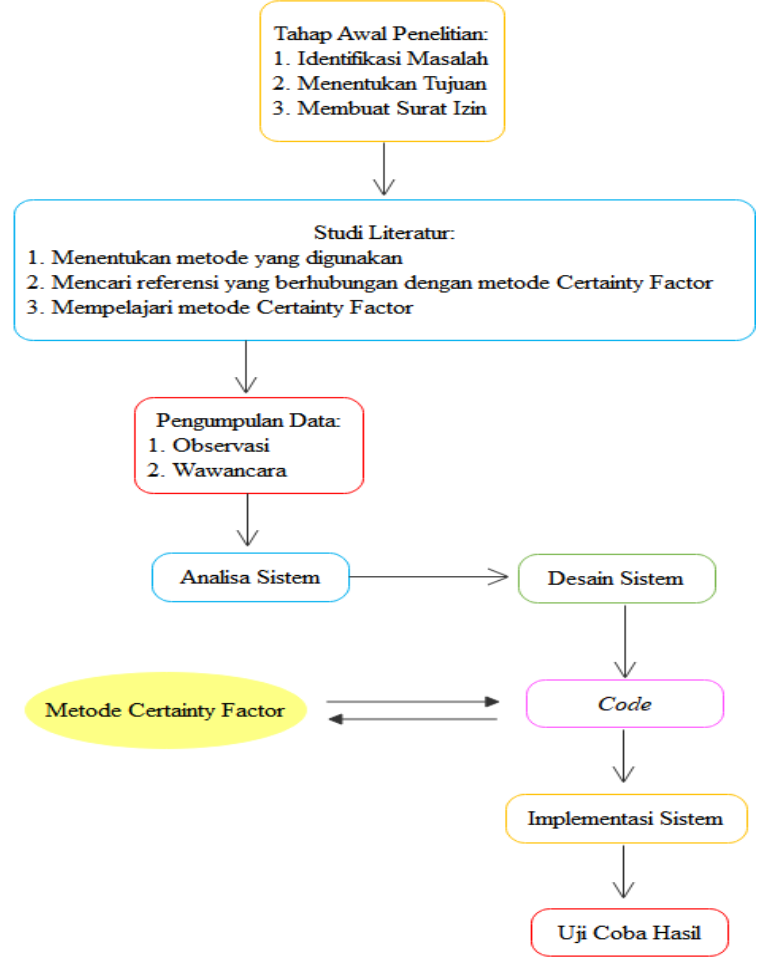

\section{Gambar 2. Kerangka Kerja Penelitian}

Berdasarkan Gambar 2, pembahasan dari uraiani kerangka kerja sebagai berikut:

1. Tahap awal penelitian

Tahapan ini diawali dengan mengidentifikasi masalah, menentukan tujuan dan kebutuhan apasaja yang dibutuhkan untuk memperoleh data.

2. Studi Literatur

Mencari landasan-landasan teori dari berbagai sumber yang berkaitan dengan analisis penyakit kelenjar getah bening.

3. Pengumpulan Data

Pada tahap ini dilakukan observasi ke tempat penelitian dan melakukan wawancara dengan pakar. Sehingga penelitian mendapatkan data yang akurat dan tidak terpaku pada studi literatur saja.

4. Analisa Sistem 
Pada tahap ini dilakukan analisa data yang dibutuhkan seperti data gejala, jenis penyakit dan pengobatan dan basis pengetahuan. Kemudian analisa proses, yaitu mencari solusi pemecahan masalah dengan metode Certainty Factor. Terakhir yaitu analisa sistem, apa saja yang dibutuhkan dalam perancangan sebuah sistem.

5. Desain Sistem

Pada tahap ini dilakukan perancangan sistem menggunakan Unified Modelling Language. Melakukan perancangan struktur data, database, desain interface, dan basis pengetahuan.

6. Code

Di mana pada tahap ini metode Certainty Factor diterjemahkan ke dalam kode.

7. Implentasi Sistem

Pada tahap ini dilakukan perancangan sistem menggunakan bahasa pemrograman PHP dan database MySQL.

8. Uji Coba Hasil

Pada tahap ini dilakukan pengujian dengan data yang telah didapatkan baik itu secara manual maupun sistem yang telah dibangun.

\section{Hasil dan Pembahasan}

Data yang digunakan dalam penelitian ialah data rekam medis pasien pada Poliklinik Bedah Onkologi Rumah Sakit Ibnu Sina Bukittinggi. Informasi mengenai data penelitian diperoleh dari sumber sekunder, dokter

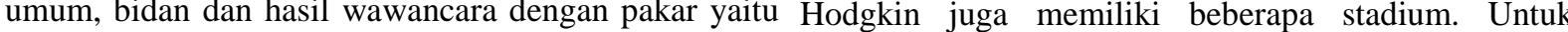
dr. Ismeldi Syarief, Sp.B(Onk). Data yang digunakan mengetahui tingkat atau level stadium hanya dapat dalam penelitian ialah 34 data gejala, 3 jenis penyakit, dilihat melalui CT scan. Berikut ini adalah data 11 cara pengobatan dan basis pengetahuan atau nilai penyakit kelenjar getah bening dapat dilihat pada tabel MB (measure belief) dan MD (measure disbelief) dari 2. seorang pakar untuk setiap gejala penyakit. Nilai MB dan MD bernilai 0 sampai 1 . Dari hasil wawancara dengan pakar maka didapatkanlah informasi mengenai data gejala penyakit kelenjar getah bening, seperti pada Tabel 1.

Tabel 1. Data Gejala

\begin{tabular}{|c|c|c|}
\hline No & Kode & Nama Gejala \\
\hline 1 & KGB-S01 & $\begin{array}{l}\text { Ada pembengkakan kelenjar getah } \\
\text { bening }\end{array}$ \\
\hline 2 & KGB-S02 & Benjolan/ bengkak pada leher \\
\hline 3 & KGB-S03 & Benjolan/ bengkak pada pipi \\
\hline 4 & KGB-S04 & Benjolan/ bengkak pada paha \\
\hline 5 & KGB-S05 & Bengkak pada kaki/ tungkai \\
\hline 6 & KGB-S06 & Benjolan/ bengkak pada dada \\
\hline 7 & KGB-S07 & Benjolan/ bengkak pada ketiak \\
\hline 8 & KGB-S08 & Flu/ influenza \\
\hline 9 & KGB-S09 & Demam dan menggigil \\
\hline 10 & KGB-S10 & Sakit kepala/ pusing \\
\hline 11 & KGB-S11 & Muntah \\
\hline 12 & KGB-S12 & $\begin{array}{l}\text { Nyeri dada, tulang, punggung, } \\
\text { perut/ limfa }\end{array}$ \\
\hline 13 & KGB-S23 & Nyeri pada benjolan/bengkak \\
\hline 14 & KGB-S14 & Mual \\
\hline 15 & KGB-S15 & Mudah letih/ lesu/ malaise \\
\hline 16 & KGB-S16 & Benjolan terasa padat/ keras \\
\hline 17 & KGB-S17 & $\begin{array}{l}\text { Gatal-gatal/ ruam di sebagian atau } \\
\text { seluruh tubuh (wajah/ area } \\
\text { benjolan) }\end{array}$ \\
\hline
\end{tabular}

18 KGB-S18 Keluar darah dalam tinja/ hidung

19 KGB-S19 Pucat

Tabel 1. Data Gejala Lanjutan

\begin{tabular}{|c|c|c|}
\hline No & Kode & Nama Gejala \\
\hline 20 & KGB-S20 & $\begin{array}{l}\text { Memiliki riwayat anemia/ penyakit } \\
\text { bawaan }\end{array}$ \\
\hline 21 & KGB-S21 & Berkeringat di malam hari \\
\hline 22 & KGB-S22 & Berat badan turun drastis \\
\hline 23 & KGB-S23 & Nafsu makan berkurang \\
\hline 24 & KGB-S24 & Kesulitan bernafas/ sesak nafas \\
\hline 25 & KGB-S25 & Gangguan pencernaan \\
\hline 26 & KGB-S26 & Benjolan tidak nyeri \\
\hline 27 & KGB-S27 & Benjolan terasa kenyal \\
\hline 28 & KGB-S28 & Tenggorokan gatal \\
\hline 29 & KGB-S29 & Susah mengeluarkan dahak \\
\hline 30 & KGB-S30 & Benjolan mudah digerakkan \\
\hline 31 & KGB-S31 & Batuk berkepanjangan \\
\hline 32 & KGB-S32 & Sakit punggung bagian bawah \\
\hline 33 & KGB-S33 & Penyumbatan aliran urin \\
\hline 34 & KGB-S34 & Benjolan pecah mengeluarkan nanah \\
\hline
\end{tabular}

Peradangan kelenjar getah bening disebabkan oleh infeksi dan kelenjar getah bening yang mengalami kanker. TBC Kelenjar Getah bening adalah penyakit kelenjar getah bening yang disebabkan oleh infeksi, Sedangkan penyakit Limfoma Maglina Non Hodgkin atau Limfoma Non Hodgkin adalah penyakit atau pembengkakan kelenjar getah bening yang telah mengalami kanker. Limfoma Maglina Non Hodgkin adalah jenis kanker atau tumor jinak dan memiliki beberapa stadium. Sedangkan Limfoma Hodgkin adalah jenis kanker atau tumor ganas, Limfoma Tabel 2. Data Penyakit

\begin{tabular}{|c|c|c|}
\hline No & Kode Penyakit & Nama Penyakit \\
\hline 1 & D01-KGB & TBC Kelenjar Getah Bening \\
\hline \multirow[t]{2}{*}{2} & D02-KGB & Limfoma Maglina Non \\
\hline & & $\begin{array}{l}\text { Hodgkin/Limfoma Non Hodgkin } \\
\text { (LMNH/LNH) }\end{array}$ \\
\hline 3 & D03-KGB & Limfoma Hodgkin \\
\hline
\end{tabular}

Dari tiga jenis penyakit ini terdapat beberapa metode pengobatannya. Data pengobatan penyakit dapat dilihat pada Tabel 3.

\section{Tabel 3. Data Pengobatan}

\begin{tabular}{|c|c|c|}
\hline No & Nama Penyakit & Pengobatan \\
\hline 1 & $\begin{array}{l}\text { TBC Kelenjar } \\
\text { Getah Bening }\end{array}$ & $\begin{array}{l}\text { Pengobatannya dengan cara } \\
\text { Biopsi (pengambilan sampel } \\
\text { jaringan) terhadap benjolan, } \\
\text { dapat diobati dengan obat } \\
\text { antibiotik (Antituberkulosis/ } \\
\text { OAT), Rontgen dada, CT Scan } \\
\text { pada leher, tes darah/ dahak. } \\
\text { Pemberian antibiotik } \\
\text { (Antituberkulosis /OAT) selama } \\
6 \text { (enam) bulan atau lebih. }\end{array}$ \\
\hline 2 & $\begin{array}{l}\text { Limfoma Non } \\
\text { Hodgkin (LNH) }\end{array}$ & $\begin{array}{l}\text { Biopsi, Radioterapi, Radiasi } \\
\text { paliatif, transplansi sumsung } \\
\text { tulang dan Kemoterapi. }\end{array}$ \\
\hline 3 & $\begin{array}{l}\text { Limfoma } \\
\text { Hodgkin (LH) }\end{array}$ & $\begin{array}{lll}\text { Biopsi, Radioterapi, } & \text { Kemoterapi } \\
\text { dan } & \text { Terapi } & \text { Kombinasi. }\end{array}$ \\
\hline
\end{tabular}

Jurnal Sistem Informasi dan Teknologi Vol . 3 No. 4 (2021) 269-274 


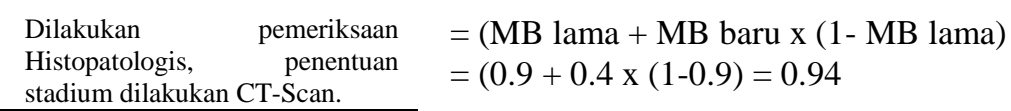

Selain data gejala, jenis penyakit dan pengobatan, data MD Sementara :

basis pengetahuan dari seorang pakar juga dibutuhkan $=($ MD lama + MD baru x (1- MD lama $)$

yaitu menentukan nilai MB dan MD dari seorang pakar. $=(0.2+0.1 \times(1-0.2)=0.28$

Dari beberapa data yang telah ada, barulah data tersebut bisa diproses menggunakan metode Certainty Factor c. Gejala $3(\mathrm{KGB}-\mathrm{S} 10)=$ Pusing, $\mathrm{MB}=0.8 \mathrm{MD}=0.02$ dengan penelusuran Forward Chaining.

\subsection{Proses Perhitungan}

$\begin{array}{ll}\text { MB Lama } & : 0.94 \\ \text { MD Lama } & : 0.28 \\ \text { MB Baru } & : 0.8\end{array}$

Pada proses perhitungan ini, dilakukan ujicoba dengan MD Baru $\quad: 0.02$ data pasien bernama S berumur 59 tahun, pasien S MB Sementara : mengeluhkan beberapa gejala di antaranya bengkak di $=(\mathrm{MB}$ lama $+\mathrm{MB}$ baru $\mathrm{x}(1-\mathrm{MB}$ lama $)$ paha kiri sebesar telur itik semenjak 5 bulan, muntah, $=(0.94+0.8 \times(1-0.94)=0.988$ flu dan pusing. Berdasarkan data gejala yang MD Sementara : dikeluhkan pasien, kemudian dilakukan perhitungan $=($ MD lama + MD baru $\mathrm{x}(1-$ MD lama $)$ dengan metode Certainty Factor sebagai berikut: $\quad=(0.28+0.02 \times(1-0.28)=0.2944$ Penyelesaian:

1. Gejala 1

D01-KGB = TBC Kelenjar Getah Bening

a. Gejala 1 (KGB-S04) = Bengkak pada paha, $\mathrm{MB}=0.4 \mathrm{MD}=0.1$

MB Lama : 0

MD Lama : : 0

MB Baru $\quad: 0.4$

MD Baru $\quad: 0.1$

MB Sementara :

$=(\mathrm{MB}$ lama $+\mathrm{MB}$ baru $\mathrm{x}(1-\mathrm{MB}$ lama $)$

$=(0+0.4 \times(1-0)=0.4$

MD Sementara :

$=($ MD lama + MD baru x (1- MD lama $)$

$=(0+0.1 \times(1-0)=0.1$

$\mathrm{CF}=\mathrm{MB}$ Sementara - MD Sementara

$$
=0.4-0.1=0.3
$$

Persentase nilai $\mathrm{CF}=0.3 \times 100 \%=30 \%$ TBC Kelenjar Getah Bening

d. Gejala $4($ KGB-S11) $=$ Muntah, $\mathrm{MB}=0.6 \mathrm{MD}=0.1$

MB Lama $\quad: 0.988$

MD Lama $\quad: 0.2944$

MB Baru $\quad: 0.6$

MD Baru $\quad: 0.1$

MB Sementara :

$=(\mathrm{MB}$ lama $+\mathrm{MB}$ baru $\mathrm{x}(1-\mathrm{MB}$ lama $)$

$=(0.988+0.6 \times(1-0.988)=0.9952$

MD Sementara :

$=($ MD lama + MD baru x (1- MD lama $)$

$=(0.2944+0.1 \times(1-0.2944)=0.36496$

$\mathrm{CF}=\mathrm{MB}$ Sementara - MD Sementara $=0.9952-0.36496=0.63$

Persentase nilai $\mathrm{CF}=0.63 \times 100 \%=63 \%$ Limfoma Non Hodgkin

3. Gejala 1 , gejala 2 , dan gejala 3 D03-KGB = Limfoma Hodgkin

2. Gejala 1 , gejala 2 , gejala 3 dan gejala 4

D02-KGB = Limfoma Non Hodgkin

a. Gejala 1 (KGB-S04) = Bengkak pada paha, $\mathrm{MB}=0.9$ $\mathrm{MD}=0$

MB Lama : :0

MD Lama : :0

MB Baru $\quad: 0.9$

MD Baru $\quad: 0.2$

MB Sementara :

$=(\mathrm{MB}$ lama $+\mathrm{MB}$ baru $\mathrm{x}(1-\mathrm{MB}$ lama $)$

$=(0+0.9 \times(1-0)=0.9$

MD Sementara :

$=(\mathrm{MD}$ lama $+\mathrm{MD}$ baru x $(1-\mathrm{MD}$ lama $)$

$=(0+0.2 \times(1-0)=0.2$

a. Gejala $1(\mathrm{KGB}-\mathrm{S} 04)=$ Bengkak pada paha, $\mathrm{MB}=0.8$ $\mathrm{MD}=0.3$

MB Lama : :0

MD Lama : :0

MB Baru $\quad: 0.8$

MD Baru : : 0.3

MB Sementara :

$=(\mathrm{MB}$ lama $+\mathrm{MB}$ baru $\times(1-\mathrm{MB}$ lama $)$

$=(0+0.8 \times(1-0)=0.8$

MD Sementara :

$=(\mathrm{MD}$ lama $+\mathrm{MD}$ baru x (1- MD lama $)$

$=(0+0.3 \times(1-0)=0.3$

b. Gejala $2(\mathrm{KGB}-\mathrm{S} 08)=\mathrm{Flu}, \mathrm{MB}=0.4 \mathrm{MD}=0.1$

MB Lama : 0.9

MD Lama $\quad: 0.2$

MB Baru $\quad: 0.4$

MD Baru $\quad: 0.1$

MB Sementara

b. Gejala $2($ KGB-S08) $=$ Flu, $\mathrm{MB}=0.3 \mathrm{MD}=0.1$

MB Lama : 0.8

MD Lama $\quad: 0.3$

MB Baru : : 0.3

MD Baru $\quad: 0.1$

MB Sementara :

$=(\mathrm{MB}$ lama $+\mathrm{MB}$ baru $\mathrm{x}(1-\mathrm{MB}$ lama $)$

$=(0.8+0.3 \times(1-0.8)=0.86$

MD Sementara : 
$=(\mathrm{MD}$ lama $+\mathrm{MD}$ baru x (1- MD lama $)$

$=(0.3+0.1 \times(1-0.3)=0.37$

c. Gejala $3($ KGB-S10) $=$ Pusing, $\mathrm{MB}=0.6 \mathrm{MD}=0.2$

$\begin{array}{ll}\text { MB Lama } & : 0.86 \\ \text { MD Lama } & : 0.37 \\ \text { MB Baru } & : 0.6\end{array}$

MD Baru $\quad: 0.2$

MB Sementara :

$=(\mathrm{MB}$ lama $+\mathrm{MB}$ baru $\mathrm{x}(1-\mathrm{MB}$ lama $)$

$=(0.86+0.6 \times(1-0.86)=0.944$

MD Sementara :

$=(\mathrm{MD}$ lama $+\mathrm{MD}$ baru x (1- MD lama $)$

$=(0.37+0.2 \times(1-0.37)=0.496$

$\mathrm{CF}=\mathrm{MB}$ Sementara - MD Sementara $=0.944-0.424=0.448=0.45$

Persentase $\mathrm{CF}=0.45 \mathrm{x} 100 \%=45 \%$ Limfoma Hodgkin (D03-KGB)

Maka dari hasil perhitungan menggunakan metode Certainty Factor di atas, kemungkinan user S menderita penyakit Limfoma Non Hodgkin dengan nilai persentase CF sebesar $63 \%$.

\subsection{Hasil Pengujian Sistem}

Setelah melakukan perhitungan manual, kemudian dilakukan pengujian perhitungan dengan sistem. Berikut ini adalah proses konsultasi pasien $S$ menggunakan sistem, dapat dilihat pada Gambar 3.

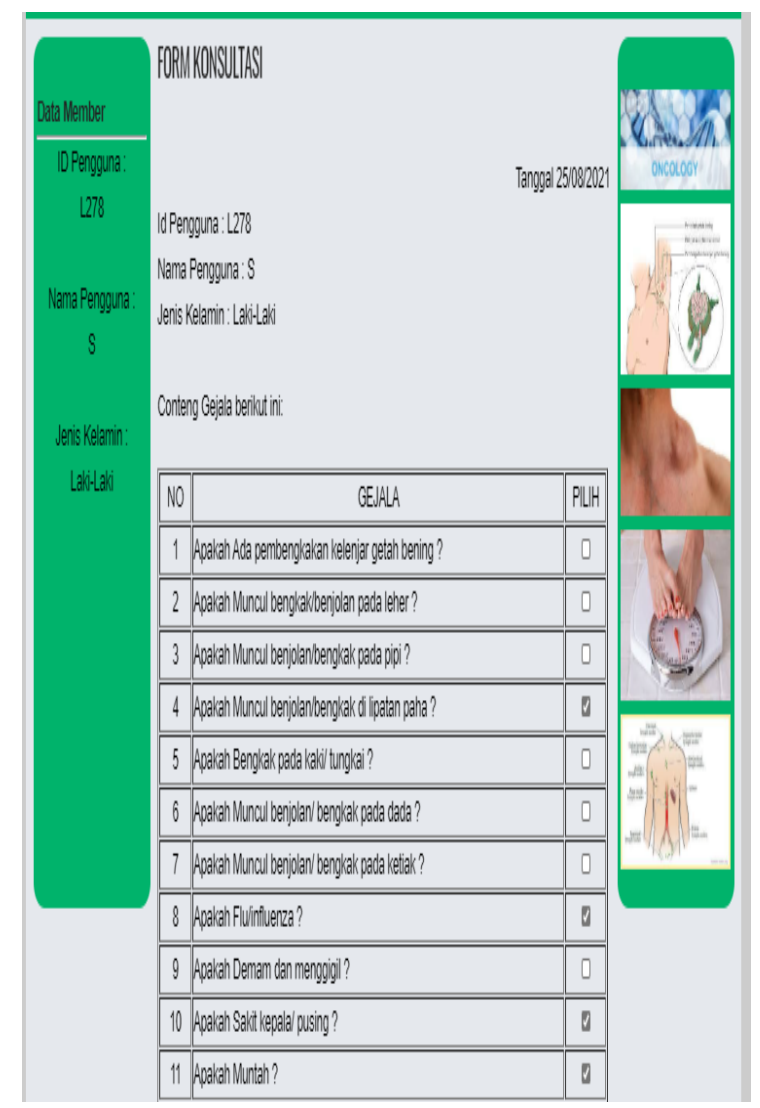

Gambar 3. Proses Konsultasi Pasien S
Berdasarkan Gambar 3, pasien S menginputkan gejala yang dialaminya yaitu mencul bengkak pada paha, flu, sakit kepala/pusing dan muntah. Setelah itu pasien akan lanjut pada proses diagnosa. Di mana tampilan hasil diagnosa Pasien dapat dilihat pada Gambar 4.

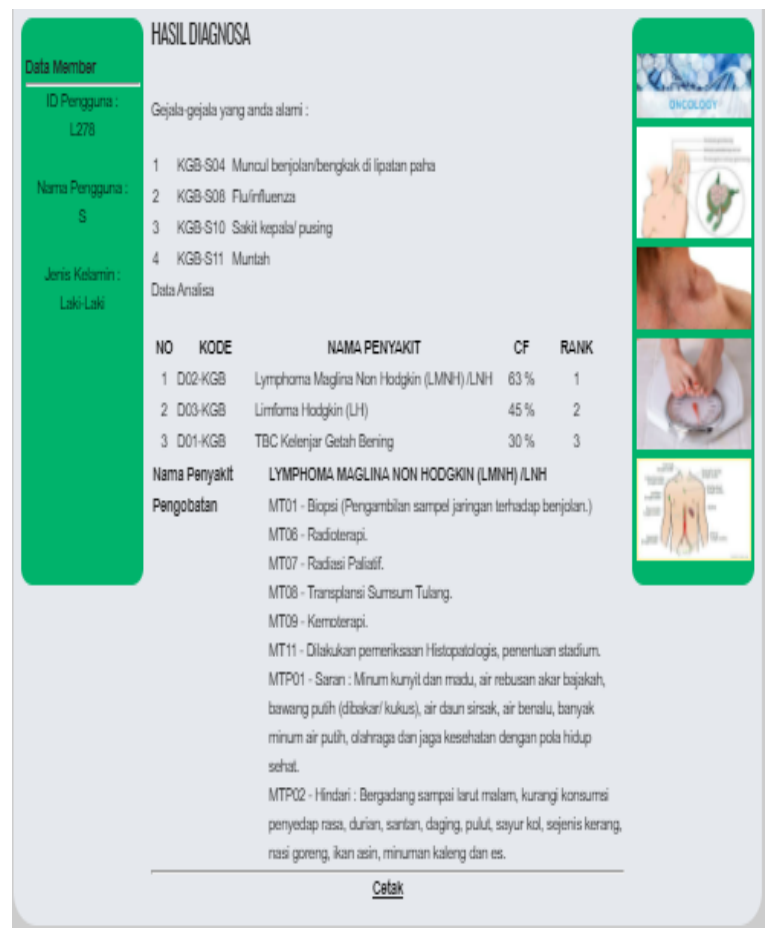

Gambar 4. Hasil Diagnosa Pasien S

Berdasarkan Gambar 3 diketahui bahwa hasil diagnosa menunjukkan pasien bernama $\mathrm{S}$ menderita penyakit Limfoma Maglina Non Hodgkin (LMNH/LNH) dengan nilai $\mathrm{CF}$ atau tingkat akurasi penyakit $63 \%$. Hasil perhitungan manual sebelumnya juga sesuai dengan hasil diagnosa Sistem Pakar dan diagnosa dokter atau pakar di rumah sakit.

Jika pasien masih keliru, pasien dapat mencetak hasil diagnosa untuk dijadikan pedoman dalam mengambil keputusan jika ingin berkonsultasi lagi ke dokter. Hasil konsultasi yang telah dicetak juga dapat menjadi bahan pertimbangan bagi dokter. Berikut hasil diagnosa atau output pasien S yang dicetak terlihat pada Gambar 5. 


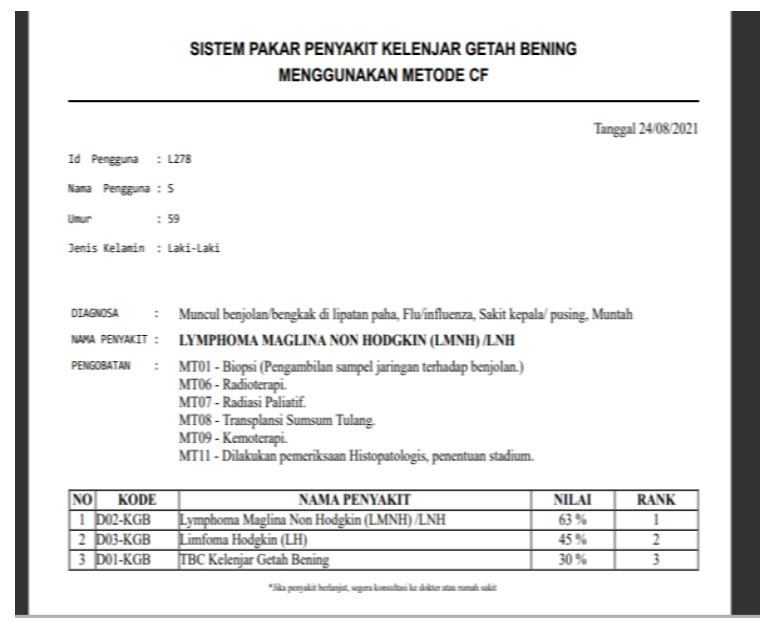

Gambar 5. Output Konsultasi Pasien S

Pada Gambar 5, hasil diagnosa yang dicetak sistem menampilkan data pengguna atau pasien berupa id pengguna, nama, umur, jenis kelamin, diagnosa gejala, nama penyakit, cara pengobatan, nilai $\mathrm{CF}$ tertinggi penyakit sampai nilai $\mathrm{CF}$ terendah dari 3 jenis penyakit. Nilai CF penyakit Limfoma Non Hodgkin 63\%, nilai CF penyakit Limfoma Hodgkin 45\%, dan TBC Kelenjar Getah Bening nilai Cfnya 30\%.

Selain dilakukan ujicoba dengan data pasien S, ujicoba juga dilakukan dengan beberapa data pasien lainnya. Hasil diagnosa pasien yang telah melakukan konsultasi dapat dilihat pada Gambar 6.

\section{Laporan Konsultasi}

\begin{tabular}{|l|l|l|l|l|l|}
\hline No. & Id Pengguna & Nama Lengkap & Umur & Penyakit & CF \\
\hline 1 & L455 & SF & 18 & Limfoma Maglina Non Hodgkin (LNNH) LNH & $61 \%$ \\
\hline 2 & L.880 & MR & 13 & Limfoma Maglina Non Hodgkin (LNNH) LNH & $68 \%$ \\
\hline 3 & L444 & SNA & 18 & Limfoma Maglina Non Hodgkin (LNNH) LNH & $48 \%$ \\
\hline 4 & L678 & IBA & 56 & Limfoma Maglina Non Hodgkin (LNNH) LNH & $63 \%$ \\
\hline 5 & L.521 & SLF & 25 & Limfoma Maglina Non Hodgkin (LNNH) LNH & $30 \%$ \\
\hline 6 & L.801 & JF & 24 & Limfoma Maglina Non Hodgkin (LNNH) LNH & $67 \%$ \\
\hline 7 & L878 & SY & 65 & Limfoma Maglina Non Hodgkin (LNNH) LNH & $56 \%$ \\
\hline 8 & L.550 & ZBZ & 54 & Limfoma Maglina Non Hodgkin (LNNH) LNH & $42 \%$ \\
\hline 8 & L.278 & S & 58 & Limfoma Maglina Non Hodgkin (LNNH) LNH & $63 \%$ \\
\hline & & & & & \\
\hline
\end{tabular}

\section{Gambar 6. Laporan Konsultasi Pasien}

Pada Gambar 6. terlihat bahwa laporan hasil konsultasi 9 orang pasien. Di mana nilai CF pasien S $63 \%$ dan nilai CF tertinggi yaitu $68 \%$ tingkat akurasi penyakit pasien bernama MR.

\section{Kesimpulan}

Berdasarkan penelitian yang telah dilakukan serta pengujian sampel terhadap data pasien yang mengalami gejala penyakit kelenjar getah bening atau peradangan kelenjar getah bening diperoleh beberapa kesimpulan.
Sistem Pakar ini berguna bagi masyarakat yang ekenomi rendah dalam menganalisis penyakit sejak dini untuk mengetahui jenis penyakit, tingkat akurasi serta cara pengobatannya. Selain itu, membantu tenaga medis, sebagai pedoman untuk pengambilan keputusan bagi pasien ataupun pakar. Dari beberapa data yang diuji, $80 \%$ hasil analisis sistem sesuai dengan analisis pakar. Salah satunya yaitu ujicoba data pasien bernama $\mathrm{S}$ diperoleh nilai $\mathrm{CF}$ dengan akurasi penyakit sebesar 63\% menderita penyakit Limfoma Maglina Non Hodgkin atau Limfoma Non Hodgkin. Dimana hasil analisis sistem sesuai dengan analisis pakar.

Untuk menjaga serta menjaga keakuratan datanya, maka perlu dilakukan proses update pengetahuan secara berkala agar sistem lebih baik lagi dalam pemanfaatannya.

\section{Daftar Rujukan}

[1] Banarjee S. (2019). Lymph Node Inspired Computing: Towords Holistic Immune System Inspired Algorithms for Human Enginereed Complex 1-13. https://doi.org/10.7287/peerj.preprintd.3150v3

[2] Agusli R., Iqbal M., \& Saputra F. (2020). Sistem Pakar Diagnosa pada Ibu Hamil dengan Metode Certainty Factor Berbasis Web. Academic Journal of Computer Science Research, 2(1), 37-25. http://dx.doi.org/10.38101/ajcsr.v2i1.264

[3] Chen, Z., Liang S., Ke Y., Yang Z. \& H. Zhao. (2017). Landslide Susceptibility Assessment Using Evidential Belief Function, Certainty Factor and Frequency Ratio Model at Baxie River Basin, NW China. Geocarto International. https://doi.org/10.1080/10106049.2017.1404143

[4] Zhao X., \& Chen W. 2019. GIS Based Evaluation of Landslide Susceptibility Models Using Certainty Factor and Funtional Trees Based Ensemble Techniques. 1-20. DOI:103390/app10010016.

[5] Wang Q., Guo Y., Li W., He J., \& Wu Z. (2019). Predictive Modeling of Landslide Hazards in Wen County, Northwestern China Based on Information Value, Weights of Evidence and Certainty Factor. 10(1), 820-835. https://doi.org/1080/19475705.2018.1549111

[6] Li J., \& Zhang Y. (2017). GIS Supported Certainty Factor Model for Assessment of Geothermal Potential: a Case Study of Tengchong County, Southwest Cina, 552-565. http://dx.doi.org/1016/j.energy.2017.09.012

[7] Widyatama R. A., \& Hansun S. (2019). Expert System for Chili Plants Disease Detection Using Certainty Factor Method. International Journal of Innovative Technology and Exploring Engineering (IJITEE) Volume 9 Issue 1, 1145-1151. DOI:10.35940/ijtee.A4440.119119.

[8] Hardi SM., Subakti F. P., \& Elviwani. (2020). Expert System for Detection Glaucoma Disease Using Certainty Factor Method. Journal of Physics Volume 1641, 1-6. DOI: 10.1088/17426596/1641/1/012100.

[9] Adrian K. (2020). Beda Ciri-ciri Kelenjar Getah Bening yang Mengalami Kanker dan Infeksi (Update 19 Maret 2020) Available at: https://www.alodokter.com [Accessed $18 \mathrm{Mei}$ 2021]

[10]Adrian K. (2020). Kenali Berbagai Penyebab Infeksi Kelenjar Getah Bening (Update 16 Maret 2020) Available at: https://www.alodokter.com [Accessed 18 Mei 2021] 
[11] Alamsyah A. P. D., \& Normalisa. (2019). Sistem Pakar Diagnosa Penyakit Ginjal", International Journal of Artificial Intelligence Volume 6 Issue 1, 53-74. DOI: 1036079/lamintang.ijai-0601.32.

[12]Fanny S. R., Hasibuan N. A., \& Buulolo E. (2017). Perancangan Sistem Pakar Diagnosa Penyakit Asidosis Tubulus Renalis Menggunakan Metode Certainty Factor dengan Penelusuran $\begin{array}{llr}\text { Forward } & \text { Chaining, } & 1(1),\end{array}$ http://dx.doi.org/10.30865/mib.v1i1.316

[13]Findawati Y., \& Afrina A. I. 2017. Expert System Diagnose Disease Dermatitis Using Web Based Certainty Factor, 1-6. DOI: 10.1088/1757-899X/403/1/012068

[14]Hayadi B. H. (2018). Sistem Pakar. Group penerbitan CV. Budi Utama: Jakarta.

[15] Isnanto R. R., Eridani D., \& Simbolon S. S. Y. W. (2018). Expert System for Diabetes Mellitus Detection and Handling Using Certainty Factor on Android-Based Mobile Device. International Journal of Health and Medical Sciences Volume 4 Issue 2, 2839. https://dx.doi.org/1020469/ijhms.40001-2

[16] Jaya H., Sabran, Idris M. M., Djawad Y. A., Ilham A., \& Ahmar A. S. (2018). Kecerdasan Buatan. Fakultas MIPA Universitas Negeri Makasar: Makasar.

[17]John K., \& E. U. Sansho. (2021). A Prospective observational Study on Lymph Node Mapping of Sentinel Lymph Node Biopsy Using Methylene Blue in Carcinoma Breast. International Surgery Journal Volume 8 Issue 1, 176-179. https://dx.doi.org/10.18203/2329-2902.isj20205877

[18]Laoli N. (2020). Ini Penyebab Kelenjar Getah Bening Bengkak (Update 22 Agustus 2020) Available at: https://kontan.co.id [Accessed 29 Maret 2021]

[19] Setiabudi W. U., Sugiharto E., \& Arini F. Y. 2017. Expert System Diagnosis Dental Dieses Using Certainty Factor Method. Scientific Journal of Information (SJI), 4(1), 43-50. http://journal.unnes.ac.id/nju/index.php/sji

[20] Marlinda J., Widiawati, Indarti W., \& Widiastuti R. (2020). Dog Disease Expert System Using Certainty Factor. Jurnal dan Penelitian Teknik Informatika, 4(2), 98-105. DOI: 10.33395/sinkron.v4i2.10538.

[21]Nasserr B. S. A. (2017). Medical Expert Systems Survey. International Journal of Engineering and Information System (IJEAIS) Volume 1 Issue 7, 218-224.

[22]Nugroho A. S. (2017). Analisis dan Perancangan Sistem Informasi. Trans Tekno: Yogyakarta.

[23]Nur A., Ikhsan D., Ariadi I., Rosyid M. B., \& Ridwan M. (2017). Perancangan Sistem Pakar Menggunakan Metode Backward Chaining untuk Diagnosa Penyakit pada Hewan Ternak Sapi Berbasis Web. 3.6-19 -3.6-24.

[24]Pangabean E. (2018). Comparative Analysis of Dempster Shafer Method with Certainty Factor Method for Diagnose Stroke
Dieses. International Journal of Artificial Intelegence Research, 2(1), 37-41. DOI: 10.29099/ijair.v2i1.53.

[25]Purnomo A. A. N., Andryana S., \& Iskandar A. 2020. Aplication of Expert System for Diagnosing Gastric Desease Android Based with Certainty Factor Method. Jurnal Teknik Informatika, 12(1), $7-15$

[26] Yunas R. A. D., Triayudi A., \& Sholihati I. D. (2021). Implementasi Sistem Pakar untuk Mendeteksi Virus Covid-19 dengan Perbandingan Metode Naive Bayes dan Certainty Factor. Jurnal Teknologi Informasi dan Komunikasi (JTIK), 338-345. https://doi.org/10.35870/jtik.v5i3.221

[27]Putri L. F. (2020). Perancangan Aplikasi Sistem Pakar Penyakit Roseola dengan Menggunakan Metode Certainty Factor. Journal Sistem Komputer dan Informatika (JSON), 1(2), 107-113. DOI: 10.30865/json.v1i2.1956.

28]Putri S. A., \& Saputra E. P. (2018). Perancangan Aplikasi Sistem Pakar Diagnosa Awal Kanker Reproduksi Wanita dengan Metode Certainty Factor. Media Informatika Budidarma 2(3), 63-68. http://dx.doi.org/10.30865/mib.v2i3.659

[29]Ramadhan P. S., \& Fatimah U. (2018). Mengenal Metode Sistem Pakar. Uwais Inspirasi Indonesia: Ponorogo.

[30]Riana F., \& Kusumah F. S. F. (2020). Expert System of Diagnosing Disease in Banana Plants Using Dempster-Shafer and Certainty Factor in Proc. $1^{\text {st }}$ International Multidisciplinary Conference on Education, Technology, and Engineering (IMCETE) 2019, 100-103. https://doi.org/102991/assehr.k.200303.025

[31]Rozitalab N. \& Nemati H. 2018. An Expert System for The Brain and Nerve Diseases in Children with Convulsion Signs Based on Certainty Factor. JMIR Medical Information. DOI:10.2196/12643.

[32] Santi I. H., \& Andari B. (2019). Sistem Pakar untuk Mengidentifikasi Jenis Kulit Wajah dengan Metode Certainty $\begin{array}{lll}\text { Factor. } & \text { INTENSIF } & \text { 159-177. }\end{array}$ https://doi.org/10.29407/intensif.v3i2.12792

[33] Setyaputri K. E., Fadlil A., \& Sunardi. (2018). Analisis Metode Certainty Factor pada Sistem Pakar Diagnosa Penyakit THT. Jurnal Teknik Elektro SINTA 2, 10(1), 30-35.

[34] Sucipto A., Fernando Y., Borman R. I., \& Mahmuda N. (2018). Penerapan Metode Certainty Factor pada Diagnosa Penyakit Syaraf Tulang Belakang. Jurnal Ilmiah FIFO, 10(2), 18-26. DOI: 102241/fifo.2018.v10i2.002.

[35] Suryana M. F., Fauziah \& Sari R. T. K. (2020). Implemntasi Sistem Pakar Menggunakan Metode Caertainty Factor untuk Mendiagnosa Dini Corona Virus Desease. Jurnal Media Informatika Budidarma, 4(3), 559-566. http://dx.doi.org/10.30865/mib.v4i3.2132 